\title{
Factors influencing the cell adhesion and invasion capacity of Mycoplasma gallisepticum
}

\author{
Ursula Fürnkranz, Karin Siebert-Gulle, Renate Rosengarten and Michael P Szostak
}

\begin{abstract}
Background: The cell invasiveness of Mycoplasma gallisepticum, the causative agent of respiratory disease in chickens and infectious sinusitis in turkeys, may be a substantial factor in the well-known chronicity of these diseases and in the systemic spread of infection. To date, not much is known about the host factors and mechanisms involved in promotion or obstruction of M. gallisepticum adherence and/or cell invasion. In the current study, the influence of extracellular matrix (ECM) proteins such as fibronectin, collagen type IV and heparin, as well as plasminogen/plasmin, on the adhesion and cell invasion levels of $M$. gallisepticum to chicken erythrocytes and HeLa cells was investigated in vitro. Two strains, $R_{\text {high }}$ and $R_{\text {low, }}$, which differ in their adhesion and invasion capacity, were analyzed by applying a modified gentamicin invasion assay. Binding of selected ECM molecules to M. gallisepticum was proven by Western blot analysis.
\end{abstract}

Results: Collagen type IV, fibronectin, and plasminogen exerted positive effects on adhesion and cell invasion of M. gallisepticum, with varying degrees, depending on the strain used. Especially strain $R_{\text {high, }}$ with its highly reduced cell adhesion and invasion capabilities seemed to profit from the addition of plasminogen. Western and dot blot analyses showed that $R_{\text {high }}$ as well as $R_{\text {low }}$ are able to adsorb horse fibronectin and plasminogen present in the growth medium. Depletion of HeLa cell membranes from cholesterol resulted in increased adhesion, but decreased cell invasion.

Conclusion: ECM molecules seem to play a supportive role in the adhesion/cell invasion process of M. gallisepticum. Cholesterol depletion known to affect lipid rafts on the host cell surface had contrary effects on cell adherence and cell invasion of M. gallisepticum.

Keywords: Extracellular matrix, Cell adhesion, Cell invasion, $\mathrm{R}_{\text {low, }} \mathrm{R}_{\text {high }}$

\section{Background}

For a long period of time, Mycoplasma spp., very small, wall-less prokaryotes, were considered obligate extracellular bacteria until in 1989 Lo et al. described intracellular organisms in an AIDS-patient, which were later identified as M. fermentans [1]. To date, other Mycoplasma spp., such as M. penetrans [2], M. genitalium [3], M. pneumoniae [4], M. suis [5], M. synoviae [6], M. bovis [7], M. hyorhinis [8], and $M$. hominis [9] have likewise been shown to be capable of invading non-phagocytic eukaryotic cells. Mycoplasma gallisepticum, the causative agent of chronic respiratory disease in chickens and infectious sinusitis in turkeys has been shown to be able to invade HeLa cells and chicken

\footnotetext{
*Correspondence: michael.szostak@vetmeduni.ac.at

Department of Pathobiology, Institute of Bacteriology, Mycology and

Hygiene, University of Veterinary Medicine Vienna, Veterinaerplatz 1, A-1210 Vienna, Austria
}

embryo fibroblasts (CEF) in vitro [10] and chicken red blood cells (RBC) in vitro and in vivo [11]. Furthermore, M. gallisepticum has been proven to cross the mucosal barrier and to spread systemically in vivo [12]. However, even closely related M. gallisepticum strains can differ markedly in their pathogenicity for chickens $[13,14]$. The strains $R_{\text {low }}$ and $R_{\text {high }}$ derive from different passages of strain $\mathrm{R}$ grown in artificial medium [14,15]. The lowpassage, hemadsorption-positive and virulent strain $R_{\text {low }}$ (10th passage) was shown to be cell-invasive in vitro and in vivo, whereas the high-passage, hemadsorptionnegative strain $R_{\text {high }}$ (164th passage) displays a highly reduced virulence and exhibits only marginal cell invasiveness [10-12,16].

Many publications over the past years addressed the bacterial proteins involved in mycoplasma cell adhesion and invasion ([17-19] for reviews). However, host factors

\section{Biomed Central}


involved in cell invasion have been investigated to a much lesser extent. The extracellular matrix (ECM) occupies the space between animal cells and is composed of secreted proteoglycans and non-proteoglycan polysaccharides or proteins like collagens, fibronectin, and laminin $[20,21]$. These macromolecules influence adhesion, migration, proliferation, and differentiation of eukaryotic cells [22], and they serve also as substrate for the attachment and internalization of pathogenic microorganisms $[23,24]$. ECM- and plasminogen-binding properties have also been reported for a limited number of Mycoplasma species like M. penetrans [25], M. hyopneumoniae [26,27], M. bovis [28] and M. gallisepticum [29-31]. So far, only for $M$. fermentans and $M$. pneumoniae an influence of ECM molecules and plasminogen on adhesion and invasion capabilities has been documented [32-34]. For M. gallisepticum strains $\mathrm{R}_{\text {low }}$ and $\mathrm{R}_{\text {high }}$, published data is limited to differential binding properties of the organism to fibronectin [29], heparin [30] and plasminogen [31].

Another host factor that plays a role in bacterial invasion processes is cholesterol, the major component of lipid rafts [35]. Cholesterol seems to play a major role in the invasion process of $M$. fermentans, as invasion rates were $70 \%$ lower in cholesterol-depleted HeLa cells, whereas adhesion rates were not influenced [32].

In the current study, our aim was to investigate hemadsorption-positive and -negative strains of M. gallisepticum for their capability to adhere to and invade HeLa cells and chicken red blood cells in the presence of selected ECM molecules and plasminogen. The role of cholesterol availability on the host cell membrane for the adhesion and invasion of M. gallisepticum was also examined.

\section{Materials and methods}

\section{Cultivation of host cells and bacteria}

Escherichia coli DH10B, Streptococcus pneumoniae type strain DSM20566 (DSMZ, Braunschweig, Germany) and Streptococcus canis strains G1 and G2 (obtained from G.S. Chhatwal, Helmholtz Center for Infection Research, Braunschweig, Germany) were used as controls in fibronectin and plasminogen binding assays. M. gallisepticum strains $R_{\text {low }}$ and $R_{\text {high }}$ were originally provided by S. Levisohn, Kimron Veterinary Institute, Bet Dagan, Israel. Mycoplasma cultures were grown in modified Hayflick medium [36] containing 20\% (vol/vol) heatinactivated horse serum (Gibco BRL, Life Technologies $\mathrm{GmbH}$, Eggenstein, Germany) and $100 \mathrm{IU}$ penicillin per $\mathrm{ml}$ (HFLX). Solid medium agar plates were produced by adding 1\% (wt/vol) bacteriological agar (Agar No. 1; Oxoid Deutschland GmbH, Wesel, Germany) to HFLX. Numbers of viable bacteria [colony forming units (CFU)] were determined as described elsewhere [16].

Chicken red blood cells (RBC) from female Lohmann Brown chicken, kindly provided by $\mathrm{C}$. Hess (Clinic for
Avian, Reptile, and Fish Medicine, University of Veterinary Medicine Vienna, Austria), were washed twice with PBS and working suspensions were adjusted to $2 \times 10^{8}$ RBC per $\mathrm{ml}$ in Dulbecco's Modified Eagle's Medium (DMEM, Gibco) containing 10\% (vol/vol) fetal calf serum (FCS, Gibco BRL) and 5\% (vol/vol) tryptose phosphate broth (Sigma). Since HeLa cells were previously used as model organisms in many mycoplasma invasion assays (e.g. $[10,33,34])$, we included this cell line. For the Gentamicin Invasion Assay (GIA), cells from the human epitheliallike cell line HeLa-229 (ATCC CCL-2.1; Manassas, VA) were washed three times with PBS, trypsinized for $10 \mathrm{~min}$ (0.05\% trypsin-EDTA; Gibco BRL), subsequently seeded in 24-well cell culture plates (Greiner Bio-One GmbH, Kremsmünster, Austria; $5 \times 10^{4}$ cells per well) and cultured for 2 days at $37^{\circ} \mathrm{C}$ in a $5 \% \mathrm{CO}_{2}$ atmosphere.

\section{Adherence and invasion assays}

The high degree of sequence homology between human, bovine and chicken fibronectin renders them experimentally interchangeable [29], which prompted us to use human fibronectin for adherence and cell invasion assays. All ECM molecules, cellular fibronectin (F2518), plasma fibronectin (F2006), collagen type IV (C5533), collagen type V (C3567) and porcine heparin (H3149), as well as plasminogen (P7999), urokinase plasminogen activator (No.124; American Diagnostica Inc., Stamford, CT), $\varepsilon$-aminocaproic acid (EACA) (A2504), and methyl- $\beta$ cyclodextrin (MßCD; C4555) were of human origin and were purchased from Sigma-Aldrich, unless otherwise indicated. The molecules were used at the following concentrations: $25 \mu \mathrm{g} / \mathrm{ml}$ for fibronectins, plasminogen, and collagens, $200 \mu \mathrm{g} / \mathrm{ml}$ for heparin, $100 \mu \mathrm{g} / \mathrm{ml}$ for EACA, $20 \mathrm{U} / \mathrm{ml}$ for urokinase plasminogen activator and $6 \mathrm{mg} / \mathrm{ml}$ for $\mathrm{M} \beta \mathrm{CD}$.

Adherence and invasion rates of $M$. gallisepticum were analyzed together in a modified GIA as described elsewhere $[10,11]$. Briefly, for the GIA using RBC, an overnight culture of $M$. gallisepticum was centrifuged at $10,000 \times \mathrm{g}$ for $10 \mathrm{~min}$, resuspended in DMEM and diluted to reach a final concentration of 4 to $8 \times 10^{4} \mathrm{CFU}$ per ml. One $\mathrm{ml}$ of this suspension was mixed with $20 \mu \mathrm{l}$ of a stock solution of the respective ECM molecules. A 250- $\mu$ l aliquot of this mixture was incubated with $250 \mu \mathrm{l}$ DMEM containing gentamicin (final concentration $400 \mu \mathrm{g} / \mathrm{ml}$ ) for $3 \mathrm{~h}$ at $37^{\circ} \mathrm{C}$ to verify the lethal concentration of gentamicin. The residual $750 \mu \mathrm{l}$ of the mixture was co-incubated for $2 \mathrm{~h}$ at $37^{\circ} \mathrm{C}$ with $750 \mu \mathrm{l} \mathrm{RBC}$ in DMEM containing $1.5 \times$ $10^{8}$ RBC. A $500-\mu l$ aliquot of this mixture was then diluted 1:10 in PBS and 100- $\mu$ l samples were plated on HFLX agar plates to count the number of input bacteria. The remaining ECM-mycoplasma-RBC mixture was divided into 2 samples, and centrifuged at $300 \times g$ for $3 \mathrm{~min}$. The resulting pellets (two per ECM molecule) were washed 
once with PBS to remove non-adherent bacteria, and resuspended in $500 \mu \mathrm{l}$ DMEM each. One resuspended pellet was further diluted 1:10 in PBS and plated on HFLX agar plates to determine the total number of adherent and intracellular bacteria. The other resuspended pellet was treated with $500 \mu \mathrm{l}$ DMEM containing gentamicin (final concentration $400 \mu \mathrm{g} / \mathrm{ml}$ ) and incubated for $3 \mathrm{~h}$ at $37^{\circ} \mathrm{C}$. After the gentamicin treatment, $100 \mu \mathrm{l}$-samples were plated to count the intracellular bacteria.

The GIA using HeLa cells was carried out in 24-well cell culture plates. If HeLa cell membranes had to be depleted from cholesterol, the cells were preincubated in the presence of $5 \mathrm{mM} \mathrm{M \beta CD}$ for $30 \mathrm{~min}$ at $37^{\circ} \mathrm{C}$ and $5 \%$ $\mathrm{CO}_{2}$ as described elsewhere [37]. After thoroughly washing to remove any $\mathrm{M} \beta \mathrm{CD}$, HeLa cells were co-incubated with $500 \mu \mathrm{l}$-samples of ECM-treated bacteria (4 to $8 \times$ $10^{4} \mathrm{CFU}$ per $\mathrm{ml}$ DMEM) for $2 \mathrm{~h}$ at $37^{\circ} \mathrm{C}$ in a $5 \% \mathrm{CO}_{2}$ atmosphere ( 2 wells per ECM molecule). After $2 \mathrm{~h}$ of incubation, the HeLa cells were washed with PBS to remove non-adherent mycoplasma, trypsinized for $10 \mathrm{~min}$ (0.05\% trypsin-EDTA; Gibco BRL) and the cells of one duplicate well were treated with $1 \mathrm{ml}$ DMEM containing gentamicin $(400 \mu \mathrm{g} / \mathrm{ml})$ to kill all extracellular mycoplasma. After $3 \mathrm{~h}$ of incubation, the number of intracellular mycoplasma was determined by plating $100 \mu \mathrm{l}$ of serial dilutions in PBS onto HFLX agar plates. The other duplicate well was used to determine the number of adherent mycoplasma and treated the same way except that no gentamicin was added. The number of input bacteria was determined from serial dilutions of mycoplasma samples before ECM treatment. All experiments were arranged in duplicate assays and repeated two $\left(R_{\text {high }}\right)$, or three $\left(R_{\text {low }}\right)$ times, respectively.

\section{Western blots}

Lysates of whole cell protein were produced from 1-ml samples of $M$. gallisepticum grown in HFLX or E. coli grown in Luria-Bertani (LB) medium according standard methods. For S. pneumoniae, biomass was collected directly from Columbia III agar plates with $5 \%$ sheep blood (Becton Dickinson, Heidelberg, Germany). Denatured whole cell proteins were separated by SDS-gel electrophoresis and transferred to nitrocellulose membranes (Whatman, Dassel, Germany). The blots were blocked with $2 \%$ blocking reagent (Blotting Grade Blocker, BioRad) and incubated with either anti-fibronectin or antiplasminogen antibodies (ABIN125555 or ABIN285631; antibodies-online $\mathrm{GmbH}$, Aachen, Germany), diluted 1:1,000 in TBS. Horseradish peroxidase-labeled goat anti-rabbit IgG (P0217; DAKO Hamburg, Germany), diluted 1:2,000, was used as the secondary antibody, and the blots were developed using 4-chloro-1-naphthol $(4 \mathrm{CN})$ according to the manufacturer's instructions (Bio-Rad).

\section{Dot blots}

One-ml samples of overnight cultures of $\mathrm{R}_{\text {high }}, \mathrm{R}_{\text {low }}$, E. coli, S. pneumoniae and S. canis were washed in equal amounts of PBS and five $\mu \mathrm{l}$ were dropped onto nitrocellulose and allowed to dry. Blocking and further processing was performed as described for Western blots.

\section{Statistical analysis}

Invasion and adhesion frequencies are expressed as the mean \pm standard deviation of $n$ independent values. Statistical analysis of the data was performed running the SPSS 18.0 software package (SPSS Inc. Chicago, USA). Group means were compared by Single-factor ANOVA and post hoc Tukey test, and P-values of $<0.05$ were considered statistically significant.

\section{Results}

The influence of ECM molecules and other factors on adhesion and invasion rates of two M. gallisepticum strains, $R_{\text {low }}$ and $R_{\text {high }}$, was investigated by a modified version of the Gentamicin Invasion Assay (GIA). The adhesion rate of strain $\mathrm{R}_{\text {low }}$ to chicken $\mathrm{RBC}$ was about $77 \%$. A slight increase was seen with EACA, alone or in combination with plasminogen or plasminogen activated to plasmin by the addition of the human urokinase plasminogen activator (Figure 1A). A more remarkable increase was observed when the hemadsorption-negative and avirulent strain $R_{\text {high }}$ was incubated together with plasmin. EACA in combination with plasminogen resulted in adhesion rates three times higher than those of $R_{\text {high }}$ alone, and fibronectin apparently decreased the adhesion capacity of $\mathrm{R}_{\text {high }}$ for $\mathrm{RBC}$.

However, standard deviations were high and thus differences were not statistically significant. The previously reported low cell invasion rates of $\mathrm{R}_{\text {low }}$ for $\mathrm{RBC}$ [11] could be confirmed and were not notably influenced by any ECM molecule (Figure 1B). A slight decrease in the mean invasion rate was observed in the presence of plasminogen. $\mathrm{R}_{\text {high }}$ showed almost no cell invasion capabilities in this set-up; only with plasminogen a significantly increased cell invasion $(p<0.05)$ was observed $(0.014 \pm 0.003 \%)$.

A positive influence on the adhesion of strain $R_{\text {low }}$ to HeLa cells was observed upon the addition of plasminogen, type IV collagen, plasminogen with EACA, and plasmin (Figure 2A). However, none of these elevations was statistically significant. $R_{\text {high }}$ exhibited eight-fold lower adhesion rates to HeLa cells than $\mathrm{R}_{\text {low }}$, however, there was a statistically significant enhancement in adhesion of $R_{\text {high }}$ when adding fibronectin $(p \leq 0.001)$, plasminogen $(p=0.022)$ or plasmin $(p \leq 0.001)$ in comparison to $\mathrm{R}_{\text {high }} \mathrm{w} / \mathrm{o}$ (Figure $2 \mathrm{~A}$ ). As all results obtained with cellular- or plasma-derived fibronectin were comparable, only the results for cellular fibronectin are shown in the figures. 

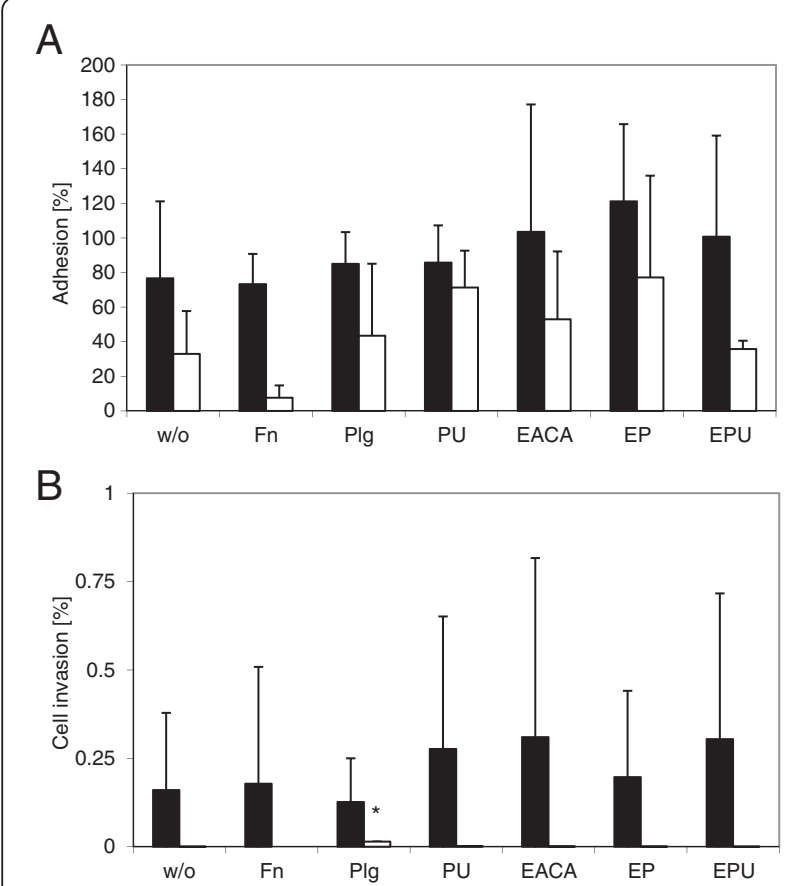

Figure 1 Influence of ECM molecules on adhesion and cell invasion of $M$. gallisepticum incubated with RBC. Mycoplasma gallisepticum $\mathrm{R}_{\text {low }}$ (solid bars) and $\mathrm{R}_{\text {high }}$ (open bars) were incubated with chicken RBC alone (w/o) or in combination with the ECM molecules fibronectin (Fn), plasminogen (Plg), plasminogen and urokinase plasminogen activator resulting in plasmin (PU), $\varepsilon$-aminocaproic acid (EACA), $\varepsilon$-aminocaproic acid and plasminogen (EP), and $\varepsilon$-aminocaproic acid, plasminogen, and urokinase plasminogen activator (EPU). The values for the adhesion (A) or cell invasion rates (B) represent the means of at least three independent experiments performed in triplicate $\left(R_{\text {low }}\right)$ or duplicate $\left(R_{\text {high }}\right) \pm$ standard deviations. A significant difference to RBC alone $(p<0.05)$ is indicated by an asterisk $\left(^{*}\right)$.

Cell invasion rates of $\mathrm{R}_{\text {low }}$ into HeLa cells were increased by the addition of plasminogen, plasmin and collagen type IV (Figure 2B). The combination of EACA with either plasminogen or plasmin decreased invasion rates. Surprisingly, we also recorded enhanced cell invasion rates of $\mathrm{R}_{\text {low }}$ with EACA alone, compared to the mean invasion rates of $R_{\text {low }}$ alone (Figure $2 B$ ).

To get an insight into the role of cholesterol/lipid rafts concerning the cell invasion and/or adhesion process, HeLa cell membranes were depleted from cholesterol using $M \beta C D$ prior to the addition of the bacteria. Whereas cholesterol depletion had a positive effect on the adhesion of $\mathrm{R}_{\text {low }}$ (Figure $2 \mathrm{~A}$ ), cell invasion was slightly decreased (Figure 2B). However, the observed differences in cell invasion were not statistically significant.

As the addition of fibronectin led to an increased adhesion of $R_{\text {high }}$ to HeLa cells, while $R_{\text {high }}$ has been reported to lack the fibronectin-binding proteins found in $R_{\text {low }}$ [29], Western and dot blot analyses of cell lysates or intact cells were performed. Fibronectin was detected on whole

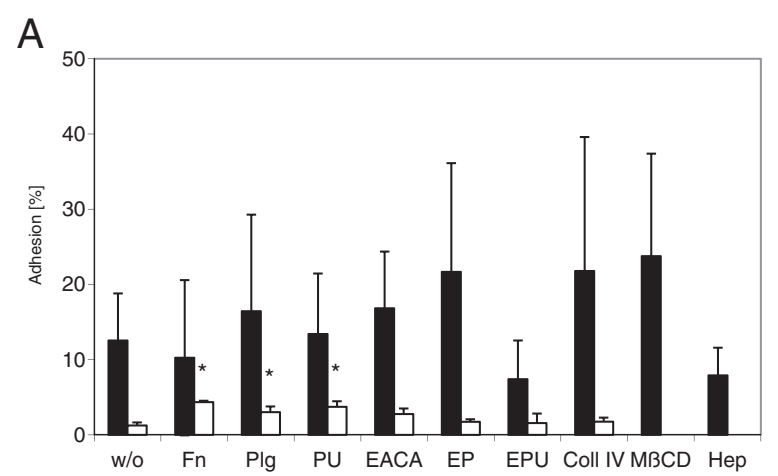

B

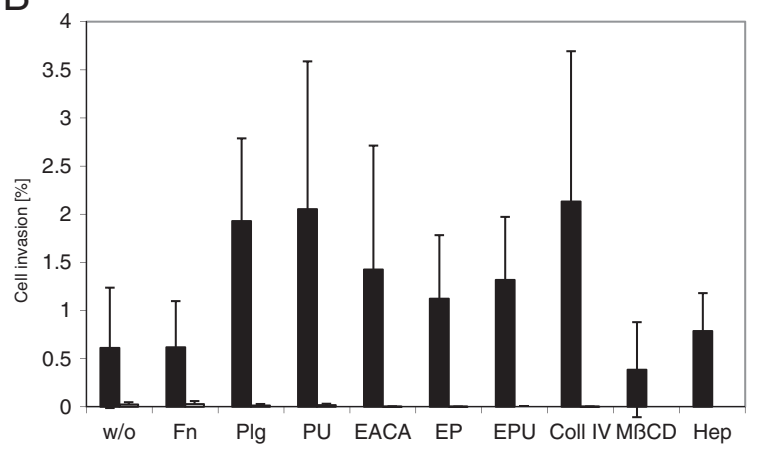

Figure 2 Influence of ECM molecules on adhesion and cell invasion of $\boldsymbol{M}$. gallisepticum incubated with HeLa cells. Mycoplasma gallisepticum $\mathrm{R}_{\text {low }}$ (solid bars) and $\mathrm{R}_{\text {high }}$ (open bars) were incubated with HeLa cells alone (w/o) or in combination with the ECM molecules fibronectin (Fn), plasminogen (Plg), plasminogen and urokinase plasminogen activator resulting in plasmin (PU), $\varepsilon$-aminocaproic acid (EACA), $\varepsilon$-aminocaproic acid and plasminogen (EP), $\varepsilon$-aminocaproic acid, plasminogen, and urokinase plasminogen activator (EPU), collagen type IV (Coll IV) or heparin (Hep). Furthermore, HeLa cells were pre-treated with methyl- $\beta$-cyclodextrin (MBCD). The values for adhesion (A) or cell invasion rates $(\mathbf{B})$ represent the means of at least three independent experiments performed in triplicate $\left(R_{\text {low }}\right)$ or duplicate $\left(R_{\text {high }}\right) \pm$ standard deviations. Significant differences $(p<0.05)$ are indicated by asterisks.

cells of $R_{\text {low }}$ as well as $R_{\text {high }}$ without the necessity of preincubating the mycoplasma cultures with supplemented fibronectin (Figure 3B). Streptococcus pneumoniae, a species known to possess fibronectin-binding proteins, also appeared positive on dot blots while $E$. coli proved negative. Western blot analysis of $R_{\text {low }}$ and $R_{\text {high }}$ cell lysates with fibronectin-specific antibodies resulted in the detection of a band at the same size as the fibronectin used as positive control or in the cell lysate of S. pneumoniae (Figure 3A). No difference regarding the occurrence of fibronectin in samples of $R_{\text {low }}$ and $R_{\text {high }}$ could be observed. When tested for the presence of plasminogen on the bacterial cell surface, both $R_{\text {low }}$ and $R_{\text {high }}$ proved positive in dot blot assays (Figure 4A). While Streptococcus canis strains G1 and G2, which were used as positive and negative controls for plasminogen binding according to a recently published report by Fulde et al. [38], exhibited 


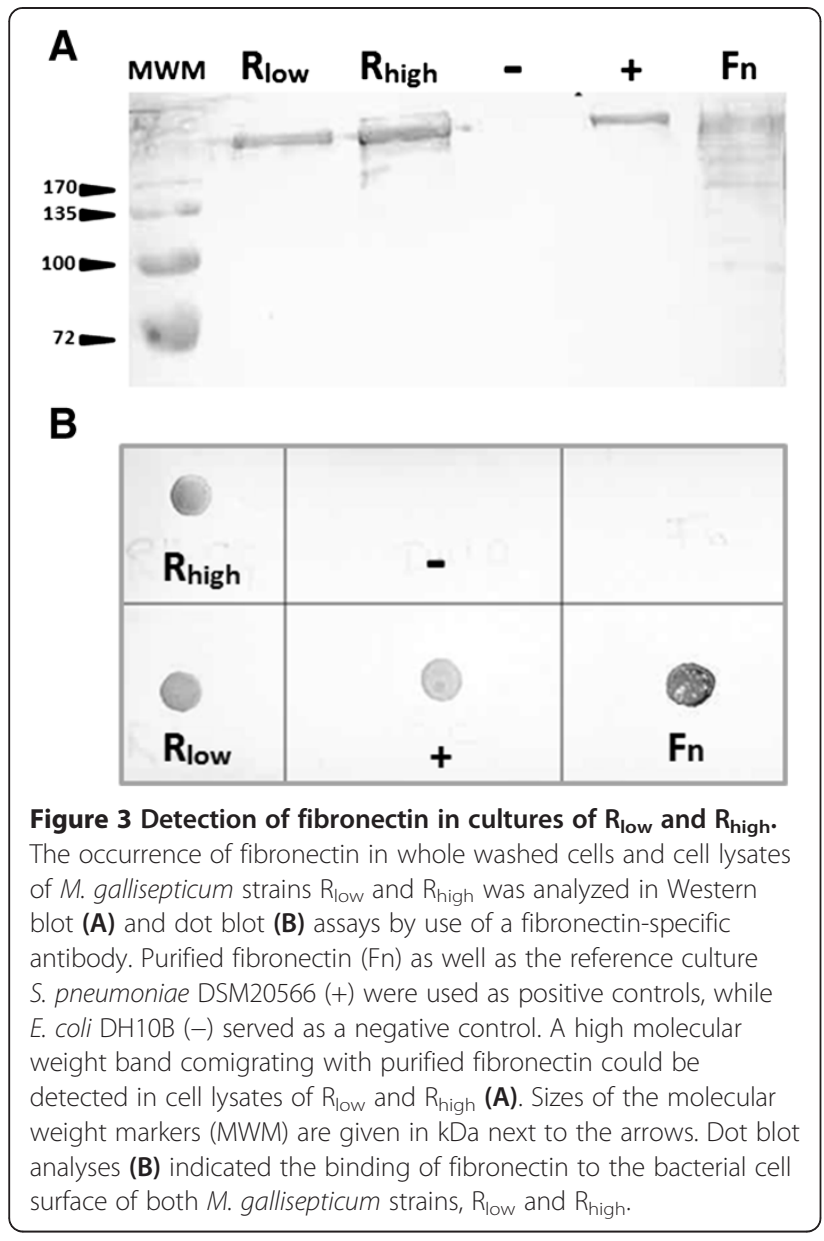

either intense or marginal reaction with the Plg-specific antibodies, $R_{\text {low }}$ and $R_{\text {high }}$ showed an equally strong reaction. On Western blots, protein bands of 158, 89, 64 and $53 \mathrm{kDa}$ were labeled in the cell lysates of $R_{\text {low }}$ and $R_{\text {high }}$ (Figure 4B).

\section{Discussion}

ECM molecules, like fibronectin or vitronectin, have been described to play a strategic role for pathogenic bacteria. They serve as a bridge component between the pathogen that binds to the ECM molecule and to host cells, which naturally have receptors for these ECM molecules $[39,40]$, thereby bringing the bacterium in close contact with the host cell. A more sophisticated exploit of interactions between ECM molecules has been described for Streptococcus pyogenes which is able to adhere to collagen via fibronectin bound to the bacterial surface [41]. Plasminogen might act similarly as a bridging component in rare events [42]. However, for cell invasive bacteria plasminogen might be of better use in its activated form, the serine protease plasmin. Besides exhibiting a crucial role in fibrinolysis and ECM remodeling, the proteolytic activity of plasmin could empower

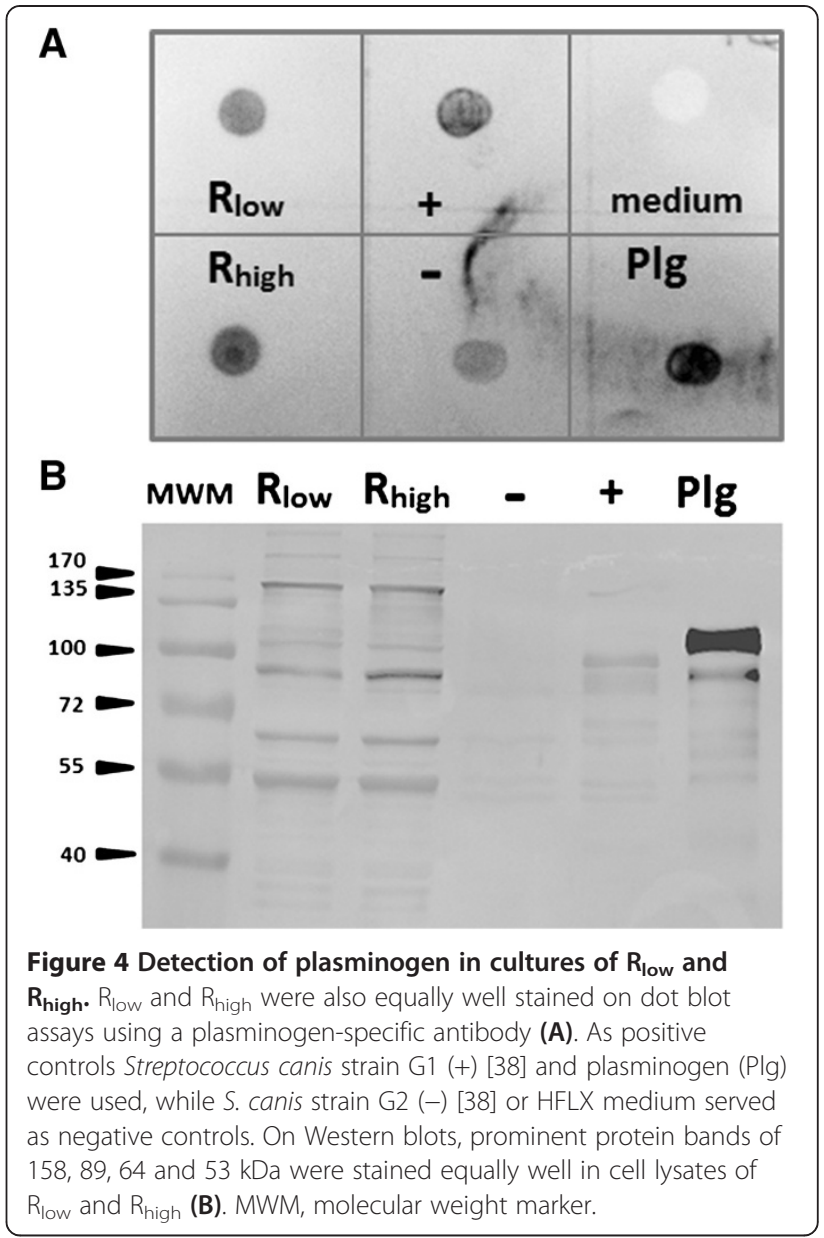

the plasmin-equipped bacterium more directly to penetrate host cells or transmigrate through monolayers, thereby assisting to cross the epithelial barrier [42-44]. M. fermentans has been shown to profit from binding to plasminogen or ECM molecules. When co-incubated with HeLa cells, $M$. fermentans exhibited an increased adherence to HeLa cells when pretreated with collagen type III or IV or plasminogen [32,34]. In this study, we report the likewise positive effect of plasminogen, as well as a slight enhancement due to fibronectin on the adherence capacity of $M$. gallisepticum. Fibronectin and plasminogen can of course be found in the serum used in the culture medium, which was proven by the ability to detect these molecules on the surface of $R_{\text {low }}$ and $R_{\text {high }}$ without further adding them (Figures 3 and 4). Nevertheless, to study their distinct effects on the invasion and adhesion capabilities of $R_{\text {low }}$ and $R_{\text {high }}$, fibronectin and plasminogen were added in abundance. The hemadsorption-positive strain $R_{\text {low }}$ showed an increased adherence to HeLa cells when preincubated with plasminogen. Strain $\mathrm{R}_{\text {high, }}$ lacking the major cytadherence proteins GapA and CrmA, exhibits drastically decreased cytadherence capacities that have been well documented [45]. However, it seems that the 
rather marginal adhesion rates of $\mathrm{R}_{\text {high }}$ to HeLa cells can be enhanced by plasminogen, plasmin and fibronectin (Figure 2A). The recruitment of plasmin or fibronectin as a bridging molecule could represent a secondary anchoring system of $M$. gallisepticum besides the primary and accessory cytadhesion proteins like GapA and CrmA. As, on the other hand, adhesion rates of $R_{\text {high }}$ with plasmin or fibronectin were still lower than adhesion rates of $\mathrm{R}_{\text {low }}$ alone, it seems that the loss of GapA and CrmA on bacterial site cannot be overcome by the ECM-mediated adhesion.

The positive effect of fibronectin on the adhesion capacity of $R_{\text {high }}$ to HeLa cells was surprising, as in 2006 $\mathrm{R}_{\text {high }}$ was reported to lack fibronectin-binding proteins [29]. When we tested whole cells and whole cell-lysates of M. gallisepticum strains $\mathrm{R}_{\text {low }}$ and $\mathrm{R}_{\text {high }}$ for fibronectinbinding properties, it turned out that fibronectin could be detected on the surface of mycoplasma whole cells as well as in cell lysates, irrespective of the strain tested. In contrast to May et al. [29], who investigated the TX-114 insoluble proteins of $M$. gallisepticum $\mathrm{R}_{\text {high }}$, we did not exclude the cytoplasmic proteins from our analyses. In M. pneumoniae, also cytoplasmic proteins like EF-Tu and PDHB were shown to appear at the surface of the mycoplasma cell and to bind fibronectin [46]. Also in other Mycoplasma species like M. genitalium, EF-Tu was found to be present at the cell surface [47]. Interestingly, although the EF-Tu proteins of $M$. genitalium and M. pneumoniae share a $96 \%$ identity, the $M$. genitalium protein does not bind fibronectin. Recently, Balasubramanian et al. showed that 3 amino acid residues (S343, P345, and T357) of the M. pneumoniae EF-Tu were essential for its binding activity to fibronectin, and that these critical amino acids are changed to alanine residues in the EF-Tu of $M$. genitalium [47]. The EF-Tu of M. gallisepticum, on the other hand, shares a lower overall identity with the EF-Tu of $M$. pneumoniae, but is higher conserved for these three Fn-binding residues (Q343,K345, T357), leaving it open to speculate about an involvement of $M$. gallisepticum $\mathrm{R}_{\text {high }}$ EF-Tu in the adhesion process by fibronectin binding.

Detection of fibronectin on the surface of $M$. gallisepticum, routinely cultured in HFLX, indicates that the fibronectin concentration in the horse serum is high enough to allow the pathogen to adsorb substantial amounts. Absorbance of protein components from the growth medium by M. gallisepticum has already been reported for transferrin or immunoglobulins [48] and for the latter IgG-binding proteins have been recognized [49]. Whether binding of fibronectin plays a role for $M$. gallisepticum in vivo, remains to be elucidated.

The influence of another family of ECM molecules, collagen type IV and V, onto $M$. gallisepticum adhesion and invasion was also investigated in the present study. Whereas collagen type $\mathrm{V}$ revealed no marked effects (data not shown), type IV collagen had a slightly positive effect on the adherence and invasion capacity of $\mathrm{R}_{\text {low }}$ to HeLa cells. For $M$. fermentans a supporting effect of collagen type III and V on the adherence capacity to HeLa cells had been reported [34]. In contrast, collagen type IV had no effect on $M$. fermentans adherence. This difference in the mode of action concerning the same family of compounds (collagens) could perhaps be explained by the different nature of the three collagens investigated, as collagen type III and $\mathrm{V}$ exhibit fibrillar structures, and are mostly found in extensible connective tissue, whereas collagen type IV is rather linked to the basal lamina. Concomitantly, this difference might also reflect the different natural habitats of M. fermentans and M. gallisepticum.

Plasminogen is not an ECM molecule per se but after its full activation to plasmin, it exerts a serine protease function on the fibrinolytic system, as well as on many ECM molecules. Binding of plasmin or plasminogen to fibrin and other ECM molecules predominantly occurs via its high- and low affinity lysine-binding sites (LBS) [50], and therefore can be easily blocked by EACA, a lysine analogue. If plasminogen is used as a bridging molecule by $M$. gallisepticum, then binding of EACA to the LBS of plasminogen should compensate for any positive effect of plasminogen on adherence and/or invasion. The results from the invasion assays support this hypothesis, as

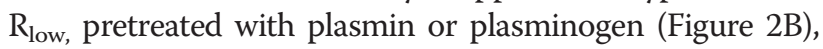
showed higher invasion rates to HeLa cells than the untreated control and addition of EACA indeed had a negative impact on the plasminogen-elevated invasion rates. For $M$. fermentans, plasminogen was shown to enhance cell invasion as well as cell adhesion [32,51], whereas no effect was seen with M. pneumoniae [33]. When we analyzed the cell adherence of $M$. gallisepticum, an increase after treatment with plasminogen or plasmin was observed (Figure 2A). To our surprise, however, EACA had no negative effect on the plasminogen-elevated cell adhesion, but rather boosted the cell adhesion. Until recently, EACA has been described as a potent inhibitor of plasminogenbinding to bacteria, [51,52], no one has yet investigated the effect of EACA alone on bacterial cell invasion or adhesion capacity. The increase in cell adhesion of $R_{\text {low }}$ and $\mathrm{R}_{\text {high }}$ in the presence of EACA alone (Figure 2A) may indicate that another $M$. gallisepticum surface protein is participating in the multifactorial adhesion process. It is well established that $M$. gallisepticum contains several cell surface proteins with hemagglutinating (pMGA/VlhA [53]), or adhesive properties like Mgc2 [54], $\alpha$-enolase [31] or the uncharacterized proteins P30, P48, P50, P80 [55].

Cholesterol depletion from HeLa cell membranes resulted in a decreased invasion capacity of $M$. gallisepticum, suggesting that cholesterol-rich regions in the cell membrane like lipid rafts are needed for the invasion process. Many bacteria have been described to enter host cells via 
receptors being present in lipid rafts and/or caveolae [reviewed by $[56,57]$. An alternative strategy for mycoplasma entry could be the engulfment via the lipid rafts. So far, entry into eukaryotic cells via engulfment without the use of receptors has only been described for very small objects like viruses and bacterial toxins [35]. Mycoplasmas belong to the smallest bacteria, they do not contain a cell wall, and their bodies seem easily deformable. M. gallisepticum has been observed to squeeze itself through 220-nm [58] and apparently even 100-nm pore filters (own observation). As lipid rafts in vivo have diameters up to $700 \mathrm{~nm}$ [57], M. gallisepticum are flexible and small enough to maybe enter the eukaryotic cell by squeezing through lipid rafts. As envisioned by others before $[17,59]$ the fusogenic properties of the mycoplasma lipidic cell wall might additionally enable the pathogen to interact with the lipid-rich raft domains. While cholesterol depletion lowered the cell invasion rates of M. gallisepticum, adherence capabilities to HeLa cells were improved. This could be explained by the fact, that cholesterol removal from membranes results in dispersion of the raft-associated lipids and proteins [56], thus destroying the possible entry site, but at the same time generating more sites for the mycoplasma to adhere to. With $M$. fermentans, plasminogen-preincubated bacteria adhered to cholesteroldepleted HeLa cells as well as to cholesterol-containing cells, but internalization of $M$. fermentans was almost completely inhibited after cholesterol depletion [32].

\section{Conclusion}

Taking these results together, it seems that M. gallisepticum is utilizing a second anchoring system besides its own primary and accessory cytadhesion proteins like GapA and CrmA that relies on the recruitment of ECM- or ECM-like molecules like collagen type IV, fibronectin or plasminogen/plasmin. Cholesterol depletion of HeLa cells had contrary effects on the adherence and cell invasion of M. gallisepticum, calling us to investigate the role of lipid rafts on the host cell surface in these mechanisms.

\section{Competing interests}

The authors declare that they have no competing interests.

\section{Authors' contributions}

MPS and RR have designed the project and helped analyzing and interpreting the results. UF and KSG carried out the experimental work, UF performed the statistical analysis. UF and MPS wrote the manuscript which all authors have read and finally approved.

\section{Acknowledgements}

We gratefully thank Drs. M. Fulde and G.S. Chhatwal (Helmholtz Center for Infection Research, Braunschweig, Germany) for providing us with S. canis strains. This work was supported by grant P20712 from the Austrian Science Fund FWF.

Received: 3 May 2013 Accepted: 31 August 2013

Published: 5 September 2013

\section{References}

1. Lo SC, Dawson MS, Wong DM, Newton PB 3rd, Sonoda MA, Engler WF, Wang RY, Shih JW, Alter HJ, Wear DJ: Identification of Mycoplasma incognitus infection in patients with AIDS: an immunohistochemical, in situ hybridization and ultrastructural study. Am J Trop Med Hyg 1989, 41:601-616.

2. Lo SC, Hayes MM, Kotani H, Pierce PF, Wear DJ, Newton PB 3rd, Tully JG, Shih JW: Adhesion onto and invasion into mammalian cells by Mycoplasma penetrans: a newly isolated mycoplasma from patients with AIDS. Mod Pathol 1993, 6:276-280.

3. Jensen JS, Blom J, Lind K: Intracellular location of Mycoplasma genitalium in cultured Vero cells as demonstrated by electron microscopy. Int J Exp Pathol 1994, 75:91-98.

4. Baseman JB, Lange M, Criscimagna NL, Giron JA, Thomas CA: Interplay between mycoplasmas and host target cells. Microb Pathog 1995, 19:105-116.

5. Groebel K, Hoelzle K, Wittenbrink MM, Ziegler U, Hoelzle LE: Mycoplasma suis invades porcine erythrocytes. Infect Immun 2009, 77:576-584.

6. Dusanic D, Bercic RL, Cizelj I, Salmic S, Narat M, Bencina D: Mycoplasma synoviae invades non-phagocytic chicken cells in vitro. Vet Microbiol 2009, 138:114-119.

7. van der Merwe J, Prysliak T, Perez-Casal J: Invasion of bovine peripheral blood mononuclear cells and erythrocytes by Mycoplasma bovis. Infect Immun 2010, 78:4570-4578.

8. Kornspan JD, Tarshis M, Rottem S: Invasion of melanoma cells by Mycoplasma hyorhinis: enhancement by protease treatment. Infect Immun 2010, 78:611-617.

9. Taylor-Robinson D, Davies HA, Sarathchandra P, Furr PM: Intracellular location of mycoplasmas in cultured cells demonstrated by immunocytochemistry and electron microscopy. Int J Exp Pathol 1991, 72:705-714.

10. Winner $F$, Rosengarten $R$, Citti C: In vitro cell invasion of Mycoplasma gallisepticum. Infect Immun 2000, 68:4238-4244.

11. Vogl G, Plaickner A, Szathmary S, Stipkovits L, Rosengarten R, Szostak MP: Mycoplasma gallisepticum invades chicken erythrocytes during infection. Infect Immun 2008, 76:71-77.

12. Much P, Winner F, Stipkovits L, Rosengarten R, Citti C: Mycoplasma gallisepticum: influence of cell invasiveness on the outcome of experimental infection in chickens. FEMS Immunol Med Microbiol 2002, 34:181-186.

13. Power J, Jordan FT: A comparison of the virulence of three strains of Mycoplasma gallisepticum and one strain of Mycoplasma gallinarum in chicks, turkey poults, tracheal organ cultures and embryonated fowl eggs. Res Vet Sci 1976, 21:41-46.

14. Levisohn S, Dykstra MJ, Lin MY, Kleven SH: Comparison of in vivo and in vitro methods for pathogenicity evaluation for Mycoplasma gallisepticum in respiratory infection. Avian Pathol 1986, 15:233-246.

15. Lin MY, Kleven SH: Evaluation of attenuated strains of Mycoplasma gallisepticum as vaccines in young chickens. Avian Dis 1984, 28:88-99.

16. Indiková I, Much P, Stipkovits L, Siebert-Gulle K, Szostak MP, Rosengarten R, Citti C: Role of the GapA and CrmA cytadhesins of Mycoplasma gallisepticum in promoting virulence and host colonization. Infect Immun 2013, 81:1618-1624.

17. Razin S: Adherence of pathogenic mycoplasmas to host cells. Biosci Rep 1999, 19:367-372.

18. Rottem S: Interaction of mycoplasmas with host cells. Physio/ Rev 2003, 83:417-432

19. Browning GF, Marenda MS, Noormohammadi AH, Markham PF: The central role of lipoproteins in the pathogenesis of mycoplasmoses. Vet Microbiol 2011, 153:44-50.

20. Hynes RO: The extracellular matrix: not just pretty fibrils. Science 2009, 326:1216-1219.

21. Kim SH, Turnbull J, Guimond S: Extracellular matrix and cell signalling: the dynamic cooperation of integrin, proteoglycan and growth factor receptor. J Endocrinol 2011, 209:139-151.

22. Raines EW: The extracellular matrix can regulate vascular cell migration, proliferation, and survival: relationships to vascular disease. Int J Exp Pathol 2000, 81:173-182.

23. Roberts DD: Interactions of respiratory pathogens with host cell surface and extracellular matrix components. Am J Respir Cell Mol Biol 1990, 3:181-186. 
24. Carneiro CR, Lopes JD: Microorganisms-extracellular matrix interactions: relation to pathogenicity-review. Mem Inst Oswaldo Cruz 1991, 86(Suppl 3):37-41.

25. Giron JA, Lange M, Baseman JB: Adherence, fibronectin binding, and induction of cytoskeleton reorganization in cultured human cells by Mycoplasma penetrans. Infect Immun 1996, 64:197-208.

26. Jenkins C, Wilton JL, Minion FC, Falconer L, Walker MJ, Djordjevic SP: Two domains within the Mycoplasma hyopneumoniae cilium adhesin bind heparin. Infect Immun 2006, 74:481-487.

27. Seymour LM, Deutscher AT, Jenkins C, Kuit TA, Falconer L, Minion FC, Crossett B, Padula M, Dixon NE, Djordjevic SP, Walker MJ: A processed multidomain Mycoplasma hyopneumoniae adhesin binds fibronectin, plasminogen, and swine respiratory cilia. J Biol Chem 2010, 285:33971-33978.

28. Bower K, Djordjevic SP, Andronicos NM, Ranson M: Cell surface antigens of Mycoplasma species bovine group 7 bind to and activate plasminogen. Infect Immun 2003, 71:4823-4827.

29. May M, Papazisi L, Gorton TS, Geary SJ: Identification of fibronectinbinding proteins in Mycoplasma gallisepticum strain R. Infect Immun 2006, 74:1777-1785.

30. Jenkins C, Geary SJ, Gladd M, Djordjevic SP: The Mycoplasma gallisepticum OsmC-like protein MG1142 resides on the cell surface and binds heparin. Microbiology 2007, 153:1455-1463.

31. Chen H, Yu S, Shen X, Chen D, Qiu X, Song C, Ding C: The Mycoplasma gallisepticum alpha-enolase is cell surface-exposed and mediates adherence by binding to chicken plasminogen. Microb Pathog 2011, 51:285-290.

32. Yavlovich A, Katzenell A, Tarshis M, Higazi AA, Rottem S: Mycoplasma fermentans binds to and invades HeLa cells: involvement of plasminogen and urokinase. Infect Immun 2004, 72:5004-5011.

33. Yavlovich A, Tarshis M, Rottem S: Internalization and intracellular survival of Mycoplasma pneumoniae by non-phagocytic cells. FEMS Microbiol Lett 2004, 233:241-246.

34. Yavlovich A, Rottem S: Binding of host extracellular matrix proteins to Mycoplasma fermentans and its effect on adherence to, and invasion of HeLa cells. FEMS Microbiol Lett 2007, 266:158-162.

35. Lafont F, van der Goot FG: Bacterial invasion via lipid rafts. Cell Microbiol 2005, 7:613-620.

36. Wise KS, Watson RK: Mycoplasma hyorhinis GDL surface protein antigen p120 defined by monoclonal antibody. Infect Immun 1983, 41:1332-1339.

37. Okubo K, Yokoyama N, Takabatake N, Okamura M, Igarashi I: Amount of cholesterol in host membrane affects erythrocyte invasion and replication by Babesia bovis. Parasitology 2007, 134:625-630.

38. Fulde M, Rohde M, Hitzmann A, Preissner KT, Nitsche-Schmitz DP, Nerlich A, Chhatwal GS, Bergmann S: SCM, a novel M-like protein from Streptococcus canis, binds (mini)-plasminogen with high affinity and facilitates bacterial transmigration. Biochem J 2011, 434:523-535.

39. Duensing TD, Wing JS, van Putten JP: Sulfated polysaccharide-directed recruitment of mammalian host proteins: a novel strategy in microbial pathogenesis. Infect Immun 1999, 67:4463-4468.

40. Chaussee MS, Cole RL, van Putten JP: Streptococcal erythrogenic toxin B abrogates fibronectin-dependent internalization of Streptococcus pyogenes by cultured mammalian cells. Infect Immun 2000, 68:3226-3232.

41. Dinkla K, Rohde M, Jansen WT, Carapetis JR, Chhatwal GS, Talay SR: Streptococcus pyogenes recruits collagen via surface-bound fibronectin: a novel colonization and immune evasion mechanism. Mol Microbio/ 2003, 47:861-869

42. Sun $\mathrm{H}$ : The interaction between pathogens and the host coagulation system. Physiology (Bethesda) 2006, 21:281-288.

43. Lahteenmaki K, Edelman S, Korhonen TK: Bacterial metastasis: the host plasminogen system in bacterial invasion. Trends Microbiol 2005, 13:79-85.

44. Attali C, Durmort C, Vernet T, Di Guilmi AM: The interaction of Streptococcus pneumoniae with plasmin mediates transmigration across endothelial and epithelial monolayers by intercellular junction cleavage. Infect Immun 2008, 76:5350-5356.

45. Papazisi L, Troy KE, Gorton TS, Liao X, Geary SJ: Analysis of cytadherencedeficient, GapA-negative Mycoplasma gallisepticum strain R. Infect Immun 2000, 68:6643-6649

46. Dallo SF, Kannan TR, Blaylock MW, Baseman JB: Elongation factor Tu and E1 beta subunit of pyruvate dehydrogenase complex act as fibronectin binding proteins in Mycoplasma pneumoniae. Mol Microbiol 2002, 46:1041-1051.

47. Balasubramanian S, Kannan TR, Hart PJ, Baseman JB: Amino acid changes in elongation factor Tu of Mycoplasma pneumoniae and Mycoplasma genitalium influence fibronectin binding. Infect Immun 2009, 77:3533-3541.

48. Bradbury JM, Jordan FT: Studies on the adsorption of certain medium proteins to Mycoplasma gallisepticum and their influence on agglutination and haemagglutination reactions. J Hyg (Lond) 1972, 70:267-278

49. Lauerman LH, Shah SM, Williams JC, Corsiglia CM, Herring RJ: Immunoglobulin receptors used in avian Mycoplasma identification. Avian Dis 1993, 37:1080-1084.

50. Markus G, DePasquale JL, Wissler FC: Quantitative determination of the binding of epsilon-aminocaproic acid to native plasminogen. $J \mathrm{Bio} / \mathrm{Chem}$ 1978, 253:727-732

51. Yavlovich A, Higazi AA, Rottem S: Plasminogen binding and activation by Mycoplasma fermentans. Infect Immun 2001, 69:1977-1982.

52. Bergmann S, Rohde M, Chhatwal GS, Hammerschmidt S: Alpha-Enolase of Streptococcus pneumoniae is a plasmin(ogen)-binding protein displayed on the bacterial cell surface. Mol Microbiol 2001, 40:1273-1287.

53. Markham PF, Glew MD, Brandon MR, Walker ID, Whithear KG: Characterization of a major hemagglutinin protein from Mycoplasma gallisepticum. Infect Immun 1992, 60:3885-3891.

54. Hnatow LL, Keeler CL Jr, Tessmer LL, Czymmek K, Dohms JE: Characterization of MGC2, a Mycoplasma gallisepticum cytadhesin with homology to the Mycoplasma pneumoniae 30-kilodalton protein P30 and Mycoplasma genitalium P32. Infect Immun 1998, 66:3436-3442.

55. Athamna A, Rosengarten R, Levisohn S, Kahane I, Yogev D: Adherence of Mycoplasma gallisepticum involves variable surface membrane proteins. Infect Immun 1997, 65:2468-2471.

56. Manes S, del Real G, Martinez AC: Pathogens: raft hijackers. Nat Rev Immunol 2003, 3:557-568.

57. Vieira FS, Correa G, Einicker-Lamas M, Coutinho-Silva R: Host-cell lipid rafts: a safe door for micro-organisms? Biol Cell 2010, 102:391-407.

58. Tully JG: Cloning and filtration techniques for mycoplasmas. In Methods in mycoplasmology. Volume 1. Edited by Razin S, Tully JG. New York: Academic; 1983:173-177.

59. Franzoso G, Dimitrov DS, Blumenthal R, Barile MF, Rottem S: Fusion of Mycoplasma fermentans strain incognitus with T-lymphocytes. FEBS Lett 1992, 303:251-254.

doi:10.1186/1751-0147-55-63

Cite this article as: Fürnkranz et al:: Factors influencing the cell adhesion and invasion capacity of Mycoplasma gallisepticum. Acta Veterinaria Scandinavica 2013 55:63.

\section{Submit your next manuscript to BioMed Central and take full advantage of:}

- Convenient online submission

- Thorough peer review

- No space constraints or color figure charges

- Immediate publication on acceptance

- Inclusion in PubMed, CAS, Scopus and Google Scholar

- Research which is freely available for redistribution 